\title{
Kernos
}

Revue internationale et pluridisciplinaire de religion grecque antique

$20 \mid 2007$

Varia

\section{The importance of sacrifice: new approaches to old methods}

\section{Gunnel Ekroth}

\section{(2) OpenEdition \\ Journals}

Electronic version

URL: https://journals.openedition.org/kernos/204

DOI: 10.4000/kernos.204

ISSN: 2034-7871

\section{Publisher}

Centre international d'étude de la religion grecque antique

Printed version

Date of publication: 1 January 2007

Number of pages: 387-399

ISSN: 0776-3824

\section{Electronic reference}

Gunnel Ekroth, "The importance of sacrifice: new approaches to old methods", Kernos [Online], 20

2007, Online since 10 February 2011, connection on 08 September 2022. URL: http://

journals.openedition.org/kernos/204 ; DOI: https://doi.org/10.4000/kernos.204

All rights reserved 
Kernos 20 (2007), p. 387-469.

\title{
Revue des Livres
}

\section{Compte rendu critique}

\author{
The importance of sacrifice: new approaches to old methods ${ }^{*}$ \\ by Gunnel EKROTH
}

The study of sacrifice in antiquity has recently been enriched by two important contributions in the form of the acta of conferences, one organized at Göteborg in 1997 and the other in Paris in 2001. The scope and aims of these two events were highly different. The Göteborg seminar focused specifically on the Olympian and chthonian aspects of Greek sacrificial ritual, while the Paris conference aimed at evaluating and broadening the work presented in the seminal study La cuisine du sacrifice en pays grec, published in $1979 .{ }^{1}$

\section{Olympian and chthonian}

Greek sacrificial ritual. Olympian and chthonian is the sixth of the seminars on ancient Greek cult organized by Robin Hägg, first at the Swedish Institute in Athens and later at Göteborg, in order to discuss a specific category of evidence or aspect of Greek cult such as iconography, epigraphy, the early Greek polis or hero-cults. ${ }^{2}$ The present volume is introduced by a brief preface in which Robin Hägg presents the idea of the seminar as being a crossdisciplinary conference where the Olympian-chthonian issue is to be addressed by scholars with diverging points of view, by diverse methods and on the basis of archaeological, iconographical, literary and epigraphical evidence.

\footnotetext{
* Review article concerning the two following books: Robin HÄGG, Brita AlROTH (eds.), Greek Sacrificial Ritual, Olympian and Chthonian. Proceedings of the Sixth International Seminar on Ancient Greek Cult, organized by the Department of Classical Archaeology and Ancient History, Götebory University, 25-27 April 1997, Stockholm, Åströms Förlag, 2005. 1 vol. $16,5 \times 24$ cm, 230 p. (Acta Instituti Atheniensis Regni Sueciae, Series in- $8^{\circ}$, 18). ISBN : 917916-049-2, and Stella GeORGOUdi, Renée Koch PiETTre, Francis ScHMidT (sous la direction de), La cuisine et l'autel. Les sacrifices en questions dans les sociétés de la Méditerranée ancienne, Turnhout, Brepols, 2005. 1 vol. $15,5 \times 24 \mathrm{~cm}, \mathrm{XV} \Pi+460$ p. (Bibliothèque de l'École des Hautes Études - Sciences religieuses, 124). ISBN : 2-50351739-0.

${ }^{1}$ M. Detienne, J.-P. Vernant et al., La cuisine du sacrifice en pays grec, Paris 1979. Translated into English by P. WISSING, The cuisine of sacrifice among the Greeks, Chicago \& London 1989.

2 The previous volumes in the series include R. HÄGG (ed.), The iconography of Greek cult in the Archaic and Classical periods, Athens \& Liège, 1992 (Kernos, suppl. 1); R. HÄGG (ed.), Ancient Greek cult practice from the epigraphical evidence. Proceedings of the Second International Seminar on ancient Greek cult, organized by the Swedish Institute at Athens, 22-24 November 1991, Stockholm, 1994 (ActaAth-8, 13); R. HÄGG (ed.), The role of religion in the early Greek polis. Proceedings of the Third International Seminar on ancient Greek cult, organized by the Swedish Institute at Athens, 16-18 October 1992, Stockholm, 1996 (ActaAth-8, 14); R. HÄGG (ed.), Ancient Greek cult-practice from the archaeological evidence. Proceedings of the Fourth International Seminar on ancient Greek cult, organized by the Swedish Institute at Athens, 22-24 October 1993, Stockholm, 1998 (ActaAth-8, 15); R. HÄGG (ed.), Ancient Greek hero cult. Proceedings of the Fifth International Seminar on ancient Greek cult, organized by the Department of Classical Archaeology and Ancient History, Göteborg university, 21-23 April 1995, Stockholm, 1999 (ActaAth-8 16). The latest volume, The Child in Ancient Greek. Cult. Proceedings of the Seventh International Seminar on Ancient Greek Cult, Göteborg University, 16-18 April 1999, is under preparation.
} 
Time was certainly ripe for a seminar on this topic. Already in 1965 Michael Jameson suggested that the polar opposition between Olympian and chthonian rituals was better replaced by dividing sacrifices into a normal type of sacrifice, thysia, and a variety of 'powerful actions', which could be used to modify, colour or even replace the thysia depending on the purpose and context of the rite. ${ }^{3}$ Similar concerns over the usefulness of the Olympian and chthonian categories have since been expressed by other scholars as well. ${ }^{4}$ The severest criticism was put forward in 1992, when Renate Schlesier (present in the audience at the Göteborg seminar) argued that the Olympian/chthonian distinction is foremost a modern, academic construct with little support in the ancient evidence. ${ }^{5}$ However, the validity of the Olympian and chthonian aspects for the understanding of Greek cult has recently also been forcefully defended by Scott Scullion. ${ }^{6}$

The present volume contains 14 papers which approach the Olympian and chthonian issue from a theoretical point of view or by focusing on a particular kind of ritual or evidence which has been regarded as central in expressing the characteristics of these two categories. ${ }^{7}$ Four contributions only appear as abstracts: Bernard Dietrich addressed the question of sacrificial ritual and its meaning in the Bronze Age versus the Iron Age, Fritz Graf the ritual distinctions between magical sacrifice and ordinary, communal sacrifices, David Reese provided a survey of faunal remains from Greek sanctuaries and Folkert van Straten discussed the iconographical evidence for priests (surprisingly slight) and their role in Greek sacrifice. The book also contains an overview of the programme of the conference, a list of the participants as well as indexes of names, literary sources, and inscriptions and papyri used.

The volume ends with a very short final discussion, which unfortunately does not replace the concluding chapter one would have wished for here, outlining evidence and methods in dealing with the Olympian and chthonian model and its validity. It is now up to the reader to construct his or her own conclusions from the contents of the papers, as well as from the discussion following each contribution, which, in accordance with the tradition of the conferences and seminars at the Swedish Institute at Athens, has been recorded and printed. In fact, the discussion reflects very well the complexities of how to understand and make use of the categories Olympian and chthonian.

\section{To retain, discard or modify?}

The volume offers a welcome first organised attempt to grapple with the difficulties in applying the concepts Olympian and chthonian, though it is evident that a model used within the study of Greek sacrifice for more than 150 years is not replaced easily and the

3 M. JAMESON, 'Notes on the sacrificial calendar from Erchia', BCH 89 (1965), p. 162-163. For the concept 'powerful actions', modelled on Nock's Heilige Handlungen, see A.D. NOCK, 'The cult of heroes', HThR 37 (1944), p. 141-173. See also G. EKROTH, The sacrificial rituals of Greek hero-cults in the Archaic to the early Hellenistic periods, Liège, 2002 (Kernos, suppl. 12), p. 310-330.

4 F.T. VAN STRATEN, Hierà kalá. Images of animal sacrifice in Archaic and Classical Greece, Leiden, 1995 (RGRW, 127), p. 165-167; A. VERBANCK-PIERARD, 'Les héros guérisseurs : des dieux comme les autres !', in V. Pirenne-Delforge \& E. SuAreZ DE la Torre (eds.), Héros et héroïnes dans les mythes et les cultes grecs. Actes du Colloque organisé à l'Université de Valladolid du 26 au 29 mai 1999, Liège, 2000 (Kernos, suppl. 10), p. 283-284.

${ }^{5}$ R. SCHLESIER, 'Olympian versus Chthonian religion', SCI 11 (1991-92), p. 38-51.

${ }^{6}$ S. Sculdion, 'Olympian and chthonian', ClAnt 13 (1994), p. 75-119; cf. idem, 'Three notes on Attic sacrificial calendars', ZPE 121 (1998), p. 116-122; idem, 'Heroic and chthonian sacrifice: new evidence from Selinous', ZPE 132 (2000), p. 163-171.

7 A list of the papers has been given in Kernos 19 (2006), p. 514 
idea of replacing it certainly creates both confusion and anxiety. ${ }^{8}$ As is rightly pointed out by many of the contributors and the discussants, the debate has just been opened.

It is interesting to note that most of the scholars participating still believe in the value of the Olympian-chthonian model for the understanding of Greek sacrificial ritual. ${ }^{9}$ Scott Scullion most clearly advocates the validity of the distinction, though with a greater degree of elasticity. His contribution constitutes an intricate argument in favour of the use of the Olympian-chthonian model, although in a modified form, in accordance with the views he presented in an important paper in $1994 .{ }^{10}$ It is argued that Zeus Soter, who is prominent in Aischylos' Oresteia, is to be seen as one example of many Doppelwesen belonging to both the Olympian and chthonian spheres. Furthermore, this view of the Olympian/chthonian mixture as portrayed in tragedy can be linked to real cult as well and especially the rituals outlined in the lex sacra form Selinous.

Scullion's modification of the model constitutes one way of demonstrating its applicability by taking into account the variability of the evidence and adapting the theoretical approach accordingly. Still, from the discussion following this paper, as well as others in the volume, it is evident that there is also a need to ascertain how far it is possible to argue for a middle ground, different from the traditionally more strict belief in the division of Greek religion into an Olympian and a chthonian sphere, respectively, without invalidating the individual and original distinction. ${ }^{11}$

An alternative approach to modification is to focus on other division and classification systems of sacrificial rituals and divinities which are to be found in the ancient evidence, apart from the Olympian and chthonian one. Albert Henrichs' contribution, "'Sacrifice as to the immortals'. Modern classifications of animal sacrifice and ritual distinctions in the lex sacra from Selinous", stresses the need for a discussion and revision of our modern notion of sacrificial categories, as well as the ancient basis for these conceptions. The binary opposition of sacrificial rituals in the Selinous inscription is taken as a test case for exploring the value of distinctions such as Olympian/chthonian or divine/heroic, asking what will be

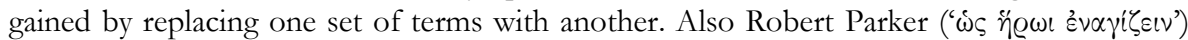
points out that an important distinction in Greek religion was between immortals and heroes, a division which is not identical with that between Olympians and chthonians. $\mathrm{He}$ approaches the issue from the sacrificial terminology, in particular the term enagizein, usually considered as specific for the sacrifices to heroes, and further tries to identify various ways in which heroic sacrifice differed from divine sacrifice. ${ }^{12} \mathrm{~A}$ similar line of argument is presented by Jan Bremmer, exploring the evidence for pregnant animals. Such victims were

${ }^{8}$ For the origins of the distinction between Olympian and chthonian, see F. CREUZER, Symbolik und Mythologie der alten Völker bersonders der Griechen³, vol. 3, Leipzig \& Darmstadt, 1842 (Deutsche Schriften, neue und verbesserte, 1:3); K.F. HERMANN, Lehrbuch der gottesdienstlichen Altertbümer der Griechen, vol. 2. Die gottesdienstlichen Alterthümer, Heidelberg, 1846; see also SCHLESIER, l.c. (n. 5).

9 Three papers do not address the Olympian-chthonian issue directly: Charlotte WIKANDER, 'The practicalities of ruler cult', who studies the veneration of Hellenistic rulers in the epigraphical evidence, demonstrating that the honours conveyed to these individuals could easily be fitted into the established cultic patterns of the Greek poleis; Nanno MARINATOS, 'Symbolic forms of sacrificial imagery in the eastern Mediterranean', discussing the mentality of sacrificial killing in Minoan, Egyptian and Mesopotamian iconography; Claude CALAME, 'Heracles, animal and sacrificial victim in Sophocles' Trachiniae' focusing on the nature of Herakles' death as represented in Sophocles' play, arguing that Sophocles especially constructed the hero's death to fit the stage.

${ }^{10}$ See Scullion, l.c. (n. 6).

${ }^{11}$ See, for example, the remarks by Renate SCHLESIER, p. 35.

12 The sacrificial rituals of Greek hero-cults, including the evidence for the use and meaning of the term enagizein, has now been analyzed in EKROTH, o.c. (n. 3), who argues that the rituals of hero-cults were the same as those for the gods apart from a small number of occasions. 
mainly sacrificed to goddesses with cults and status which somehow can be said to be different from 'normal', anthropomorphic gods, or in rituals marking the transition between youth and adulthood. Instead of classifying these sacrifices as chthonian, as has frequently been done, Bremmer explains them as distinct from other rituals by having 'negative' connotations (the meaning of 'negative' is unfortunately not defined by Bremmer). ${ }^{13}$

Henrichs and Parker are concerned with the central question to what extent our modern terminology has to depend on the ancient one and whether Olympian/chthonian is better replaced by divine/heroic or immortal/mortal, which has direct support in the ancient evidence, or by positive/negative or marked/unmarked, which are modern interpretations and denominations of the binary divisions encountered in the ancient evidence. It has to be remembered that while chthonian gods and beings can be identified both as an ancient and a modern notion, the criteria for what constitutes chthonian rituals are harder to grasp, since they do not depend on any ancient usage.

The only paper which openly questions the validity of using the Olympian/chthonian designations is by Kevin Clinton, who investigates the great variety of ritual uses of pigs and piglets in the literary and epigraphical evidence, many of which have been labelled chthonian due to the connections between pigs and the earth. Clinton emphasizes the distinctions in the meaning of 'chthonian' and the importance of keeping apart the two senses of this term, on the one hand, as connected with living earth and fertility gods and, on the other, as linked to the underworld and the realm of the dead. ${ }^{14} \mathrm{He}$ argues that the modern application of 'chthonian' is of little use when explaining rituals involving pigs apart from the deposition of piglets at the Thesmophoria and sacrifices of pregnant sows, and then only in the sense of involving agrarian fertility. ${ }^{15}$ Another difficulty with the application of Olympian and chthonian as strictly distinct categories is brought out by Christoph Auffarth, namely how traditions of correct Olympian or chthonian sacrificial practices could have been handed down and upheld in a society where there were no professional priestly caste or fixed written prescriptions. He concludes that there seems to have been no compulsion for a formalistic application of Olympian or chthonian rituals, rather there was an urge to keep within 'normality', as opposed to the discourse on deviating sacrifices found within myth.

It is evident that the Olympian-chthonian model is based almost exclusively on literary texts. The papers addressing epigraphy, archaeology and osteology are therefore particularly interesting. In the light of the Selinous lex sacra, Birgitta Bergquist retracts her previous

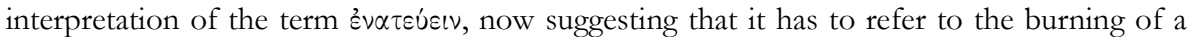
ninth of the sacrificial victim. The two attested cases of this ritual on Thasos, both for Herakles, are to be understood as prohibiting such sacrifices, thus resulting in the rituals for this divinity being taken as regular thysia sacrifices at which all of the meat could be eaten. Bergquist's new interpretation in fact removes the evidence for a chthonian cult of Herakles on this island. ${ }^{16}$ Carla Antonaccio's article ('Dedications and the character of cult')

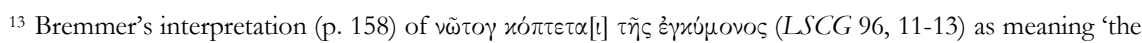
back of the pregnant sow having to be broken' seems unwarranted. This stipulation more likely refers to the good meat along the back of the victim being cut out in one piece and used for ritual and honorary purposes.

${ }^{14}$ See also K. Clinton, Myth and cult. The iconography of the Eleusinian Mysteries. The Martin P. Nilsson lectures on Greek religion, delivered 19-21 November 1990 at the Swedish Institute at Athens, Stockholm, 1992 (ActaAth-8 , 11), p. 61, esp. n. 189; idem, 'A new lex sacra from Selinous: kindly Zeuses, Eumenides, impure and pure Tritopatores, and elasteroi', CPb 91 (1996), p. 168-169, with n. 36 and n. 39.

15 Among the many interesting points made in Clinton's paper is also the fact that the purification by piglets was not only accomplished by the piglet's blood but most of all by burning its body in a holocaust.

${ }_{16}$ This is in line with recent work on the cult and nature of Herakles, relegating the chthonian side primarily to myth, see A. VERBANCK-PIÉRARD, 'Le double culte d'Héraklès : légende ou réalité ?', in A.-F. 
investigates the offerings at the sanctuary of Helen and Menelaos at Therapne, Lakonia, in order to see whether they were used to construct a chthonian aspect of this cult. Not surprisingly, the rich variety of votives, especially the small lead miniatures, are very difficult to match to either Olympian or chthonian recipients or rituals.

One of the most interesting papers of the volume is Elizabeth Gebhard's and David Reese's study 'Sacrifices for Poseidon and Melikertes-Palaimon at Isthmia', discussing the osteological evidence from this sanctuary. The Archaic-Classical deposits at the Long Altar contained heavily burned bones, among which thighbones were especially prominent, but also other parts of the animal were apparently burnt. Unburnt bones come from a large reservoir to the south-west of the temple, where the dining must have taken place during the same periods. Three pits in the precincts of the hero Melikertes-Palaimon were filled with the remains of holocausts of cattle, a ritual corresponding to the traditional notion of a chthonian hero-cult. However, it is important to note that these remains date to the mid-1st to early 3rd centuries $\mathrm{AD}$ and might in fact constitute a change in cult practice when the cult of this hero was reintroduced after the Roman re-settlement of Corinth. ${ }^{17}$ The papers by Bergquist, Antonaccio and Gebhard/Reese clearly illustrate that the information we encounter in the literary sources needs to be confronted with other kinds of evidence of Greek ritual practices and that the disparities definitely should be explored. The fact that the Olympian and chthonian categories are difficult to identify outside a small number of literary sources raises the question if this distinction is valid for Greek religion at large.

The volume also reveals the extent to which modern preconceived notions of the existence of Olympian and chthonian categories and of what is covered by each of these often direct the interpretations of the evidence. For example, when discussing sacrifices at which the victims were plunged into water, Noel Robertson presupposes the ritual to go back to Mycenaean times (without providing any specific evidence) and originally to have functioned as a kind of sympathetic magic. Later the practice became assimilated to both Olympian and chthonian sacrifices depending on the emphasis of ritual details such as libation, blood-letting or the scattering of parts of the victim. Olympian and chthonian are here taken as self-evident and clear-cut categories with no further need for definition or reflection. The effect of the modern notions are also illustrated by Dennis Hughes' wellargued and clear study 'Sacrifice and the cult of the dead in ancient Argos', which explores the funerary rituals at Argos as outlined in Plutarch's 24th Greek Question. Previous commentators on this passage have found it difficult that a sacrifice to Apollo is said to follow the funeral and have therefore postulated a chthonian divinity instead of the Olympian god. Hughes shows that the polluted state of the family was ended by a sacrifice to Apollo Lykeios after which new fire and meat (enknisma) were brought to the house from the god's sanctuary, a ritual sequence in which a sacrifice to Apollo makes perfect sense and so there is no need to try to 'correct' the text.

On the whole, the book offers little comprehensive discussion of what the Olympian and chthonian distinction is to be based on: the actual rituals, the character of the divinity or the occasion when the sacrifice was performed, and how we can actually define and apprehend Olympian and chthonian in the ancient evidence. Though the contributors display a will to distance themselves from the old and traditional terminology and its applications, many central aspects of the conventional use of Olympian and, in particular, of

LAURENS (ed.), Entre hommes et dieux. Le convive, le héros, le prophète, Paris, 1989 (Lire les polythéismes, $2=$ Centre de recherches d'histoire ancienne, 86$)$, p. 43-65.

${ }^{17}$ For the changes in the Roman cult of Palaimon, see M. PIÉRART, 'Panthéon et hellénisation dans la colonie romaine de Corinthe : la « redécouverte» du culte de Palaimon à l'Isthme', Kernos 11 (1998), p. 85109; EKROTH, o.c. (n. 3), p. 80-82. 
chthonian are taken for granted and used. A scrutiny, in detail, would be needed of whether features such as nightly sacrifices, black victims, outpourings of blood, ritual terms such as choai, the burning of meat and the bending of the victim's head towards the ground really can be regarded as 'chthonian' or if they are unfounded assumptions. ${ }^{18}$

In conclusion, any die-hard Olympian-chthonian adherents à la Paul Stengel are not likely to surface anymore. ${ }^{19}$ Though the papers presented here do not venture as far as asking for a discarding of the model, the outcome is that they at least call for a definition of what is covered by Olympian and chthonian and how these categories can be used. Hopefully, this interesting study will result in the model no longer being taken for granted when studying Greek sacrifice and each scholar henceforth will ponder why and on what basis the categories are to be applied and to what extent they might help to clarify the ancient evidence.

\section{Kitchen and altar}

The second volume discussed here, La cuisine et l'autel, grew out of a series of seminars culminating with a table ronde organized in Paris in 2001 at the École Pratique des Hautes Études. The inspiration of the book is to be found in La cuisine du sacrifice en pays grec, published in 1979 under the aegis of Marcel Detienne and Jean-Pierre Vernant. In the extensive introduction, Stella Georgoudi, Renée Koch Piettre and Francis Schmidt state that La cuisine et l'autel aims at testing the validity of the conclusions put forward in that very important volume, many of which have become fundamental for the scholarship on Greek sacrifices, but also at reconsidering and re-examining the field of sacrifice by posing new questions and widening the scope geographically and chronologically to include also Egypt, ancient Israel and the Roman world to allow for comparisons to be made with the Greek evidence. Not only alimentary animal sacrifice is dealt with, but also vegetable offerings, holocausts and purifications. The role of the gods within sacrifice is stressed as well, shifting the focus from sacrifices exclusively. This wider perspective will allow the reader both to grasp the particularities of the sacrifices of each period and location, and to discern the resemblances and differences.

The book contains 23 papers organized in four thematic sections, each of which divided into subsections. ${ }^{20}$ The first deals with definitions of what constitutes killing, offering or eating in a ritual context, the offerings of food and vegetables, and rituals which seem to fall outside the traditional boundaries of what constitutes a sacrifice. The second part concerns violence, sacralization and elimination, and focuses on the treatment of the sacrificial victim and the regulations surrounding the ritual activity. The third part addresses the relations between gods and men in the context of banqueting and division of the offerings. The final part focuses on what happens to sacrificial systems when they come in contact with other cultures and religions, or drastic changes take place. The book ends with a brief biography of each author followed by indexes of personal names, general matters and terms in Egyptian, Hebrew, Greek and Latin.

La cuisine et l'autel offers a wealth of information on sacrifice in antiquity which certainly both broadens and deepens the work presented in La cuisine du sacrifice en pays grec. The latter

\footnotetext{
18 The bending down of the victim's head towards the ground at sacrifices seems rarely to have been executed due to practical difficulties and cannot be taken as a 'chthonian' trait, see EKROTH, o.c. (n. 3), p. 269276.

${ }^{19}$ See, for example, P. STENGEL, Opferbräuche der Griechen, Leipzig \& Berlin, 1910, esp. p. 126-145; idem, Die griechischen Kultusaltertümer ${ }^{3}$, Munich, 1920 (HdA, 5:3), esp. p. 95-153.

${ }^{20}$ For the order of the individual papers, see the list in Kernos 19 (2006), p. 512-513.
} 
volume had a strongly pronounced theoretical focus in its approach to Greek sacrificial ritual and has become more or less the 'sacred text' for many scholars working in this field. The anthropological approach of the 'French school' is now both widely used and wellestablished. ${ }^{21}$ La cuisine et l'autel is, however, surprisingly devoid of theoretical issues. Instead, the evidence itself with all of its profound complexity lies at the centre. The material focused on is mainly literary with some epigraphy and occasional archaeological additions. Iconography as a source for cult practice is addressed by some of the contributors but the scant use of this kind of evidence constitutes a marked difference from La cuisine du sacrifice en pays grec, in which the two chapters by Jean-Louis Durand dealing with Attic vase-painting fundamentally increased our understanding of Greek cult. ${ }^{22}$ Furthermore, the lack of illustrations in some of the papers in La cuisine et l'autel dealing specifically with iconography is unfortunate. ${ }^{23}$

The wider chronological and geographical spectrum covered, not only Archaic and Classical Greek, but also Roman, Egyptian, Hebrew and Christian, is particularly welcome and serves to contextualize sacrifice in a manner not done (or even desired) in La cuisine $d u$ sacrifice. This wider scope has resulted in several of the contributions having the character of an overview and review of evidence for a specific kind of sacrifice, sacrificial practices or issues of scholarly debate within a particular culture and a particular period. This, however, is far from negative, since the volume offers the reader a wide range of information and therefore stimulates comparisons and reflections.

If we begin with the thysia sacrifice, the central ritual of Greek cult, La cuisine et l'autel offers important insights highlighting the complexity of the empirical evidence which sometimes was overlooked by the theoretical approach in La cuisine du sacrifice. Guy Berthiaume ('L'aile ou les mêria. Sur la nourriture carnée des dieux grecs') focuses on a concrete aspect of Greek thysia sacrifice, whether only the bare thighbones would be burnt or the entire leg with the meat still attached to it. The division of the animal victim and the handling of its bones as presented in the Theogony (538-541) constituted a starting point for Detienne's and Vernant's interpretation of thysia sacrifice. ${ }^{24}$ Since the term meria can mean both thigh and thighbone, Berthiaume suggests that in many cases the entire, fleshy leg would be burnt as the god's portion, the choice depending on the piety or generosity of the individual worshipper.

Stella Georgoudi confronts one of the paradigms of La cuisine du sacrifice en pays grec, the notion that Greek sacrificial ritual aimed at concealing the violence done to the victim. ${ }^{25}$

\footnotetext{
${ }^{21}$ For an example, see S. PEIRCE, 'Death, revelry, and thysia', ClAnt 12 (1993), p. 219-266.

22 J.-L. DURAND, 'Greek animals: toward a topology of edible bodies', p. 87-118, and 'Ritual as instrumentality', p. 119-128, in Cuisine of sacrifice, o.c. (n. 1).

${ }^{23}$ See the paper by Mareile HAASE, 'Etruskische Tieropferdastellungen: Bild und Handlung'. None of the two Etruscan scenes, which her study concerns, a bronze mirror and an amphora, are illustrated, which makes the argument difficult to follow, see ThesCRA I, p. 152-153, no. 127, for the bronze mirror, now in Florence, and ThesCRA I, p. 153, no. 128 for the amphora, now in Dresden. Also the Françoise LABRIQUE's contribution ('Le bras de Sekhmet') would have profited from more illustrations.

${ }^{24}$ M. DETIEnNE, 'Culinary practices and the spirit of sacrifice'; J.-P. VERnANT, 'At man's table: Hesiod's foundation myth of sacrifice', in o.c. (n. 1).

${ }^{25}$ Illustrating GEORGOUDI's paper (Fig. 5) are three photographs of a very interesting Campanian redfigure oinochoe (the Rainore vase), previously known only from an early 19th-century drawing, see ThesCRA V, p. 307-308, no. 999 (drawing); cf. A.D. TRENDALL, The red-figured vases of Lucania, Campania and Sicily, London 1967, p. 254, no. 188; VAN STRATEN, o.c. (n. 4), p. 216, no. V125. The vase depicts three youths proceeding to a sacrifice, the first one carrying a boar, the second one a hammer, a bundle of spits and a knife, and the third one a metal tray for the meat and wood for the fire. The tray is central for the understanding of the appearance of Athenian marble cult table tops, see D.H. GILL, Greek cult tables, New York \& London, 1991 (Harvard dissertations in classics), p. 83-84 and fig. 29.
} 
The hiding of the machaira, the sacrificial knife, plays an important role in this construct, but the importance of this action has surely been exaggerated, as was demonstrated in 1999 in a paper by Pierre Bonnechere, on which Georgoudi builds part of her discussion. ${ }^{26}$ Based on archaeological and iconographical evidence Georgoudi further challenges the notions of the willing victim and the feelings of guilt surrounding sacrifice. At real sacrifices, victims were probably neither unrestrained nor peaceful, judging from the stone blocks with metal rings found in sanctuaries as well as the reliefs depicting animals being attached by ropes. The feelings of guilt associated with sacrifice have surely been exaggerated by pressing Porphyry's account of the Bouphonia too far, and it is questionable whether this Attic festival can be considered as relevant for the Greek evidence in general. ${ }^{27}$ Also Folkert van Straten's paper argues for a more diversified view of thysia sacrifice by underlining the different emphases conveyed by different kinds of evidence, especially regarding the killing of the victim and the handling of the splanchna as a way of strengthening the ties, not only between the worshippers, but also between men and gods.

But La cuisine et l'autel also offers a more inclusive approach to Greek sacrifice by incorporating other kinds of ritual activities and types of offerings apart from the thysia performed with an animal victim and concluded by a meal. The study of the ritual world of the Greeks certainly deserves a wider perspective in which thysia only constitutes one part.

Louise Bruit Zaidman examines the role and function offerings of vegetables and other foodstuffs within the wider spectrum of sacrificial ritual and relations between men and gods, certainly an understudied field in Greek religion. ${ }^{28}$ She explores how the paradox of the immortal gods being given food of the kind consumed by mortals worked as a means for constructing the relations between gods and men more precisely. Of central interest for the understanding of these rituals is the interplay between burning offerings on the altar and depositing them on a trapeza, as well as inviting the gods to dine at a theoxenia ceremony, making them partake of the human food though not eating together with the worshippers. In the philosophical discourse, an opposition between vegetable and animal offerings is pronounced, which is less evident in the actual, practised cult.

The previous explicit focus on thysia has also led to the neglect of a number of other rituals within Greek cult. In a detailed contribution, Renée Koch Piettre ('Précipitations sacrificielles en Grèce ancienne') investigates rituals at which the offerings were plunged into water or thrown into an abyss. Starting from the question whether one can sacrifice by throwing something away, she contextualizes this action within the Greek terminology for throwing, discarding and libating, as well as within the ritual language of discarding the offerings and destroying them. Hurling the offerings can be compared with sphagia, oathtaking and other offerings where the animal was not eaten. Still, to sacrifice by throwing away must be conceived as a proper sacrifice, a kind of thysia, though with connotations of gift-giving in a violent form.

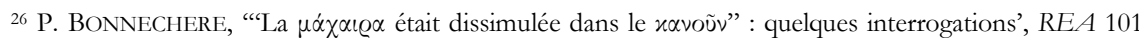
(1999), p. 21-35.

${ }^{27}$ This point has also been argued by A. HENRICHS, 'Dromena und Legomena. Zum rituellen Selbstverständnis der Griechen', in F. GRAF (ed.), Ansicbten griecbischer Rituale. Geburtstags-Symposium für Walter Burkert, Castelen bei Basel 15. bis 18. Mär. 1996, Stuttgart \& Leipzig, 1998, p. 58-63.

${ }^{28}$ Louise BRUIT ZAIDMAN has certainly contributed more than any other scholar in bringing out the importance of offerings of food for the gods, see, for example, L. BRUIT, 'Sacrifices à Delphes. Sur deux figures d'Apollon', RHR 201 (1984), p. 339-367; eadem, 'Les dieux aux festins des mortels: théoxénies et xeniai', in LAURENS, o.c. (n. 16), p. 13-25; eadem, 'The meal at the Hyakinthia: ritual consumption and offering', in O. MurraY (ed.), Sympotica. A symposium on the symposion, Oxford, 1990, p. 162-174; eadem, Le commerce des dieux. Eusebeia. Essai sur la piété en Grèce ancienne, Paris, 2001 (Textes à l'appui). 
Disposal of unwanted objects within a ritual context is also examined by Athanassia Zografou. The paper surveys both the kinds of items eliminated (e.g. water used for purification, clothes from the sick, but also remains of sacrifices) and the locations where this was done. To prevent any pollution from these items spreading, they were neutralized by consecration, thus linking elimination and offering. The notion and meaning of destruction within Greek sacrificial ritual is discussed by Jesper Svenbro ('La thusia et le partage. Remarques sur la 'destruction' par le feu dans le sacrifice grec'). His starting point is a critique of the use of the term 'destruction sacrifice' in my dissertation on the sacrificial rituals of Greek hero-cults. ${ }^{29}$ Svenbro argues that this term is unsuitable, since the burning of the offerings served to transform and make them accessible for the gods. All sacrifices established a kind of commensality with the gods, even holocausts where the entire animal is burnt, and the burning at an enagismos or at a thysia. ${ }^{30}$

The majority of the contributions in the book do not focus on Greek sacrifice of the Archaic and Classical periods. Two papers deal with the discourse on Greek sacrifices in texts from the Imperial period. Laurent Pernot ('Le sacrifice dans la littérature grecque de l'époque impériale') points to the richness of the Imperial sources for the study of Greek sacrifice but also emphasizes the difficulties in using this evidence. In the novels, Heliodoros' Aethiopica, for example, sacrifice functions as an element of decoration and atmosphere rather than as a reflection of contemporary cult. Also Aelius Aristides and Lucian represent sacrifice from a literary point of view, focusing on the extraordinary cases, such as human sacrifice, at the cost of ordinary cult, although Aristides falls back on his personal experiences. Porphyry's Philosophy from oracles is analyzed by Stéphane Toulouse, arguing that it is not an early work, but must be counted among the author's later philosophical productions. Of central interest to Porphyry is the inner and intellectual sacrifice by which man purifies and sanctifies himself to god. These papers bring out important methodological points similar to those made in the recent work on evaluating Pausanias as a source for Greek religion, both of his own and earlier periods. ${ }^{31}$ Methodological concerns are also addressed in Mareile Haase's article, 'Etruskische Tieropferdastellungen: Bild und Handlung'. Haase questions the extent to which Etruscan iconography can be used as evidence for practised, Etruscan cult, especially the cult of Dionysos, and argues that the iconography incorporates elements distinctly referring to Greek rituals. The depictions are therefore to be seen as elements of the Etruscan discourse on Greek culture rather than as representations of local ritual practices.

Three papers on Roman ritual focus on the function and interpretation of dining in sanctuaries and in connection with sacrifices. John Scheid ('Manger avec les dieux. Partage sacrificiel et commensalité dans la Rome antique'), explores the practicalities and interpretation of Roman public banquets, which would have involved large numbers of

${ }^{29}$ The printed version of this work, which appeared in 2002 (see EKROTH, o.c. [n. 3]), should preferably have been referred to instead of the unpublished manuscript from 1999.

${ }^{30}$ I agree with Svenbro that a holocaust is not a 'destruction' from the point of view of the gods, who actually received more at these rituals (a point I also made in the dissertation of 1999, p. 109, n. 471, and the printed version of 2002 , o.c. [n. 3], p. 129 , n. 1), but I want to emphasize that my aim with using the term 'destruction sacrifice' was to create a useful category to facilitate the understanding of the practical execution of the sacrificial rituals of hero-cults, not to pass a theological judgement of the meaning of these actions.

${ }^{31}$ G. Eкroth, 'Pausanias and the sacrificial rituals of Greek hero-cults', in Ancient Greek hero cult, o.c. (n. 2), p. 145-158; V. Pirenne-Delforge, 'Les rites sacrificiels dans la Périégèse de Pausanias', in D. KNOEPfler \& M. PiÉrarT (eds.), Éditer, traduire, commenter Pausanias en l'an 2000. Actes du colloque de Neuchatel et de Fribourg (18-22 septembre 1998), Genève, 2001, p. 109-134; eadem, 'Ritual dynamics in Pausanias: the Laphria', in E. Stravrianopoulou (ed.), Ritual communication in the Graeco-Roman world, Liège, 2006 (Kernos, suppl. 16), p. 111-129. 
people in cities like Rome. Scheid opposes the notion that public banquets are to be considered 'secular' and separated from animal sacrifice or the ritual slaughter to procure meat. $^{32}$ After re-examining the evidence he concludes that all slaughter in Roman society must have been ritual to some degree, even when procuring salted meat for future consumption, and that it could not have been possible to kill an animal without sharing it with the gods in some sense.

Jörg Rüpke's contribution 'Gäste der Götter - Götter als Gäste: zur Konstruktion des römischen Opferbanketts' discusses the fact that in Roman society, unlike the Greek, a strong link between animal sacrifice to the gods and banquets for men was never pronounced (though Rüpke seems to overestimate the degree to which the Greek gods were considered as actually eating with the mortal worshippers). ${ }^{33}$ The unequal relationship between gods and men could not be accommodated within the context of a banquet. The gods would dine by themselves at the lectisternia while the dining for humans was confined to the conuinium publicum, just as there were strict social hierarchies among the groups of men who were to dine together. The practicalities of ritual are also addressed by Ulrike EgelhaafGaiser, 'Sakrallandschaften und Tafelluxus: Adaptation und Naturinszenierung in Banketträumen pompejanischer Kultgemeinschaften', who discusses the architecture and decoration of dining-rooms in sanctuaries and private buildings in Pompeii. Dining spaces in Pompeian sanctuaries, even those of a more simple and rustic kind, were embellished to resemble the interiors of private houses and villas, a development which can be seen as a result of an increased taste for luxury and comfort in the local community.

The comparisons between Greek and Hebrew sacrificial practices and terminology offered in La cuisine et l'autel are revealing as well as fruitful, especially in the light of strong resemblance between Greek and Hebrew sacrificial practices and the suggestions that the Greek thysia may have been influenced by Israelite rituals or even introduced from the Near East in the Early Iron Age. ${ }^{34}$ A concrete comparison of the understanding of rituals in these two cultures is presented by Gilles Dorival ('L'originalité de la Bible grecque des Septante en matière de sacrifice'), investigating the terminology used by the translators of the Septuagint to render the Hebrew sacrifices. A literal translation was not made, as the Greek often uses a greater number of terms to render the sacrifices of the original text. New terms were also created to translate the biblical rituals, but it is interesting that a number of central Greek ritual terms, such as biereion and hieros, were not employed at all.

Three other papers deal with Israelite rituals and illustrate further distinctions from the Greek evidence as to the killing, offering and handling of the meat. Alfred Marx ('Tuer, donner, manger dans le culte sacrificiel de l'ancien Israël') argues that the killing of the animal victim was not considered part of the actual sacrifice at Hebrew rituals. Central was instead the homage and tribute paid to God, and the offerings were not considered as gifts, since God could not be given what already belonged to him. The cooking and consumption of the meat functioned primarily as a way to distinguish levels of commensality between

32 In particular, SCHEID argues against the opinions expressed by M. KAJAVA, 'Visceratio', Arctos 32 (1998), p. 109-131.

${ }^{33}$ For a discussion of the relation men and gods at Greek sacrifices, see M.H. JAMESON, 'Theoxenia', in Ancient Greeke cult practice from the epigraphical evidence, o.c. (n. 2), p. 55-57.

${ }^{34}$ For sacrifices, see B. BERGQUIST, 'Bronze Age sacrificial koine in the Eastern Mediterranean? A study of animal sacrifice in the ancient Near East', in J. QUAEGEBEUR (ed.), Ritual and sacrifice in the ancient Near East: Proceedings of the International Conference organized by the Katholieke Universiteit Lewven from the 17th to the 20th of April 1991, Leuven, 1993 (Orientalia Lovaniensia analecta, 55), p. 11-43; W. BURKERT, 'Greek tragedy and sacrificial ritual', GRBS 7 (1966), p. 102, n. 34; idem, Homo Necans. The antbropology of ancient Greek sacrificial ritual and myth, Berkeley, 1983, p. 9-10; idem, Greek religion. Archaic and Classical, London, 1985, p. 51; cf. J.P. Brown, Ancient Israel and ancient Greece. Religion, politics and culture, Minneapolis, 2003. 
God, priests and the invited participants. Christophe Batsch discusses whether herem, a ritual found in war contexts in ancient Israel, is to be considered as a sacrifice. This term is used for two different categories, objects or goods vowed to a divinity in a manner that they cannot be taken back, and destruction of idolatrous cities. Herem cannot be considered as a sacrificial ritual, but still it has to be accompanied by sacrifice when executed and actually recalls a votive offering. Finally, the interpretation of legislation in the Torah concerning the slaughter of animals and the consumption of sacrificial and profane meat is explored by Francis Schmidt. Three types of meat can be distinguished, each linked to a particular type of space, and by the handling of the meat, a separation between sacred and profane areas could be upheld.

One of the best sections of the volume concerns the transformations of the notion of Greek and Roman sacrifice and the attitudes to sacrificial ritual within Christian culture. Three very interesting, well-written and well-argued papers address these issues. The antipagan legislation from Constantine to Theodosius II is discussed by Nicole Belayche ('Realia versus leges? Les sacrifices de la religion d'État au IVe siècle'). On the basis of the 4th-century laws, pagan worship and especially animal sacrifice have often been considered as having been under attack. Belayche convincingly demonstrates that, in reality, public sacrifice was not a concern for the Imperial administration before the end of the century and that much of the critique of animal sacrifice actually came from within pagan circles. Private divination by haruspicy was banned earlier, since it was thought to be used for magical purposes, which might hurt the power of the emperor. An illustration of the Christian concept of sacrifice is given by Joan Branham ('Women as objects of sacrifice? An early Christian 'Chancel of the virgins"). Starting from a marble slab from a chancel screen in a Roman church in North Africa she discusses how such screens were used to distinguish different kinds of space, sacred, social and gendered, and thus to develop a sense of hierarchy in the church. While widows were compared with altars, virgins were viewed as objects of sacrifice, keeping their bodies pure as an offering to God. As such they were revered and set apart within the church. The third paper, by Cristiano Grottanelli ('Tuer des animaux pour la fête de Saint Félix'), offers a sophisticated analysis of how ritual slaughter within pagan cult was distinct from Christian sanctified butchery, focusing on Paulinus' description of the epulum for St Felix at Nola, written in AD 406. To kill animals and eat their meat in a religious context cannot simply be explained as a survival and continuation of old customs, as it often has been, and is to be seen rather as a Christian interpretation of the traditional votum.

The articles dealing with animal sacrifice in ancient Egypt, both in Pharaonic and later periods, constitute the step furthest away from the Greek evidence. The Egyptian material is illuminating as to how the meaning and use of sacrifice were fundamentally different compared with Greek and Roman practices. Such distinctions caution against simplistic comparisons between cultures. Two papers deal with the recognition of violence within Egyptian animal sacrifice. Catherine Bouanich ('Mise à mort rituelle de l'animal, offrande carnée dans le temple égyptien') demonstrates that the representation of a violent killing of animals, in particular wild species, served as a metaphor for Pharaoh slaying his enemies with force. The slaughtering of edible animals is hardly ever depicted. The meat from the victims was partly given to the priests but there seems to have been no communal dining. The link between animal victims and enemies is also analyzed by Françoise Labrique on the basis of the reliefs at the Ptolemaic temple of Khonsu at Karnak. The goddess Sekhmet is shown as a lioness which with an iron brands the animal victims shown as enemies, whom the king will kill with the help of the divinity. Catherine Graindorge offers a reinterpretation of the Egyptian festival of the god Min. She goes against the scholarly consensus that the white bull, led in a procession at this festival, was sacrificed after being given a sheaf of corn. Graindorge demonstrates that there is no evidence for the animal being slaughtered 
and that the vegetable offering was presented to the bull, which then came to symbolize the principle of royal regeneration.

The Egyptian evidence stands a little apart from the rest of the material covered in the book. If a departure from the hellenocentric perspective was wished for, one wonders why Egypt was included and not Mesopotamia, Assyria and Anatolia (especially the Hittites), considering the influence of these cultures on the formation of Greek religion. ${ }^{35}$ Hittite sacrificial practices are at present the focus of intensive study, which will certainly be of major interest for scholars of Greek religion. ${ }^{36}$ Also the Aegean Bronze Age is significant in this context, as recently published osteological evidence from Methana and Pylos has provided new possibilities for addressing the question whether Greek animal sacrifice as we know it from the historical period, was practised already in the Mycenaean period. ${ }^{37}$

La cuisine et l'autel is a significant and stimulating study which will be useful to all scholars working on sacrifices in the ancient Mediterranean cultures. One objection has to be made, however. Since one of the aims of the book was to widen the focus to contextualize both Greek sacrifice and scholarship on this topic, it is surprising that it was not considered important to include contemporary scholarship outside the French-speaking sphere to a greater extent. This somewhat indifferent view of non-French scholarly activity is detected in the references as well, where a number of new and central works written in English or German are left out. When discussing sacrificial cakes, Louise Bruit makes no mention of Emily Kearns' paper from 1994, while Renée Koch Piettre exclusively refers to scholarship in French on human sacrifice, passing over Dennis Hughes' volume, which actually preceded that of Pierre Bonnechere. ${ }^{38}$ There is no reference to the important Festschrift to Walter Burkert, Ansichten griechischer Rituale, which was published in 1998, nor to Jörg Gebauer's study of the iconography of Greek animal sacrifice. ${ }^{39}$ A Francocentric attitude is also evidenced in many of the English abstracts of the papers, which unfortunately cannot have been checked by a native speaker, since some sentences are so grammatically and syntactically flawed that they are almost incomprehensible.

\section{Perspectives: Olympian and chthonian or kitchen and altar?}

Since these two volumes to a large extent cover different fields of study, it might be of little use to make comparisons. Incidentally, one scholar was actually present at both events,

${ }^{35}$ See W. BurKerT, The orientalizing revolution. Near Eastern influence in Greek culture in the early Archaic age (Revealing antiquity 5), Cambridge, Mass. \& London, 1992; M.L. WEST, The east face of the Helicon. West Asiatic elements in Greek poetry and myth, Oxford, 1997, esp. p. 33-59.

${ }^{36}$ See latest the work by Alice MOUTON, 'Anatomie animale : le festin carné des dieux d'après les textes hittites I. Les membres antérieurs', Colloquium anatolicum III, 2004, p. 67-92; eadem, 'Anatomie animale : le festin carné des dieux d'après les textes hittites II. Les membres postérieurs et d'autres parties anatomiques', Colloquium anatolicum IV, 2005, p. 139-154; eadem, 'Le porc dans les textes religieux hittites', in B. LION \& C. MiCHel (eds.), De la domestication au tabou : le cas des suidés dans le Proche-Orient ancien, Paris, 2006 (Travaux de la Maison René-Ginouvès, 1), p. 255-265, with accompanying bibliographies.

37 Y. HAMILAKIS \& E. KONSOLAKI, 'Pigs for the gods: burnt animal sacrifices as embodied rituals at Mycenaean sanctuaries', OJA 23 (2004), p. 135-151; V. ISAAKIDOU et al., 'Burnt animal sacrifice at the Mycenaean 'Palace of Nestor', Pylos', Antiquity 76 (2002), p. 86-92; P. HALSTEAD \& V. ISAAKIDOU, 'Faunal evidence for feasting: burnt offerings from the Palace of Nestor at Pylos', in P. HALSTEAD \& J.C. BARRETT (eds.), Food, cuisine and society in prehistoric Greece, Oxford, 2004 (Sheffield studies in Aegean archaeology, 5), p. 136154. Cf. R. HÄGG, 'Ritual in Mycenaean Greece', in Ansichten griechischer Rituale, o.c. (n. 27), p. 99-113.

${ }^{38}$ E. KEARNS, 'Cakes in Greek sacrifice regulations', in Ancient Greek cult practice from the epigraphical evidence, o.c. (n. 2), p. 65-70; D.D. HugHes, Human sacrifice in ancient Greece, London \& New York, 1991.

${ }^{39}$ Ansichten griechischer Rituale, o.c. (n. 27); J. GeBAuer, Pompe und Thysia. Attische Tieropferdarstellungen auf schwarz- und rotfigurigen V asen, Münster, 2002 (Eikon, 7). 
Folkert van Straten. However, apart from distinctions as to actual factual matter, the 37 papers show that the study of ancient ritual and sacrifice can still basically be perceived as divided into two 'schools', one German-Anglophone and one Francophone, a division which is visible in the theoretical and methodological approach as well as in the attitudes to scholarship in a wider, international perspective. Unfortunately the books make few attempts to bridge over this divide.

The differences in methodological and theoretical approach can be illustrated by two papers, one in each volume, which deal with the same topic, the act of sacrificing offerings by throwing them into water. Noel Robertson interprets this ritual as very old, originally working as a kind of sympathetic magic and gradually entering the Greek system to become assimilated to other types of rituals within the Olympian and chthonian structure, that is, an evolutionary approach to the issue. Renée Koch Piettre, on the other hand, firmly focuses on the Greek evidence of the historical period, especially from a semantic point of view by analysing in great detail the terminology of throwing and discarding and by contextualizing the significance and many possible meanings of such actions.

The most striking difference, however, is that the Olympian-chthonian issue, being the focus of the Göteborg seminar, is all but absent in La cuisine et l'autel (briefly mentioned on p. 32, 46 and 85 and with only one reference in the index, to p. 32). A topic worthy of major investigation and discussion among one group of scholars appears to be more or less of a non-issue for another scholarly community. This has historical reasons of course. The importance of the Olympian-chthonian model has always been fundamental in German and British scholarship (and still is) while French work on sacrificial ritual has focused on aspects where such a model cannot be traced or is of little importance. It is interesting to note that Claude Calame, a scholar who belongs to the 'French' paradigm, in his contribution to the Olympian and chthonian volume actually does not address the central issue in spite of focusing on Herakles, a deity often evoked as a prime expression of the Olympian and chthonian facets of Greek religion. It would be interesting to further explore the history of scholarship of ancient sacrifice with attention paid to distinctions in theoretical approaches in relation to the nationality and background of the scholars involved. ${ }^{40}$

Greek sacrificial ritual, Olympian and chthonian and La cuisine et l'autel illustrate clearly that in spite of the work done on ancient sacrifice this is a field that will not be exhausted for a long time to come. By evaluating and discussing old paradigms, both volumes open up a plethora of new issues and venues, for example, the need to move away from primarily sacrificial ritual to include also the role and meaning of the divine party, the possibilities offered by animal bones and recent discoveries such as the Selinous lex sacra, and the huge and interesting work that is still to be done on comparisons between different cultures and periods. The inclusion and mixture of different kinds of evidence is to be desired, as is the inclusion and mixture of scholars of different perspectives, traditions and origins.

University of Stockholm

E-mail: Gunnel.Ekroth@antiken.su.se

${ }^{40}$ See, for example, W. BuRKERT, Greek religion, o.c. (n. 34), p. 4 and p. 217 (who indeed does not fully endorse the Olympian/chthonian paradigm), critizising the French structuralism as ahistorical and concerned with formal models, while J.-P. Vernant, Mortals and immortals. Collected essays, Princeton, 1991, p. 279, questions the validity of Burkert and Karl Meuli in explaining and comparing sacrifices 'with what can be but dimly perceived in the hunting rituals of Palaeolithic times'.

${ }_{41}$ The importance of this inscription for our understanding of Greek sacrificial ritual can hardly be exaggerated, see M.H. JAMESON, D.R. JORDAN \& R.D. KOTANSKY, A lex sacra from Selinous, Durham, 1993 (GRBM, 11); cf. CLINTON, l.c. (n. 14), p. 159-179; for recent commentaries on the text, see also E. LuPU, Greek sacred law. A collection of new documents (NGSL), Leiden, 2005 (RGRW, 152), p. 359-387, no. 27. 